村㛿人の生活上労倘について

女子美術大学, 順天堂大学公租衛生学教 角由淃造

A. 緒䓂

渏玉県の蚊とはえのいない村の運動で模䩞になつてい る静村さ，人交科学者，自然科学者による綜合調查をし

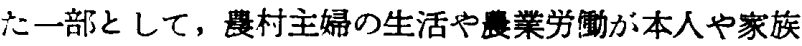
の健康に如何に影㸷しているかを調査したその実態を報 告し，健亦な村造り運動の资料としたい。

\section{B. 調查方法}

予備調查の結果，役場资料などをるとにして，倳業と 経済状態で周化系統抽出された世带，101 戸につき，昭 和31年 8 月 20 日より10日間にわたり主婦に面接調查 した。

C. 調查の結果と考察

I 主婦の生活

調查の結果を要約すれば，贯家主婦の生活について は，(1）睡眠時間は一般に主人や他の家人に較へて少 く，自由時盟は農繁期では全くないといつてよい状態で ちる.（2）食事の什度や片付は费算期には主婦に变つ一 姑が行5ようになるが，それでる約半数の家定は主媂自 身で行つている，その方法として，朝食と昼食の淮備を

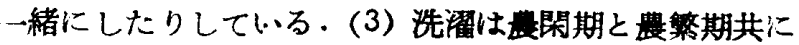
主婦が行5が，春良仕事の寸樶を惜んで行つている。

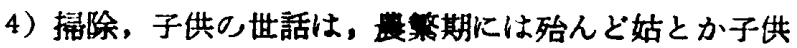
こまかせているが，農閉期です䄪半数の家庭は姑や子供

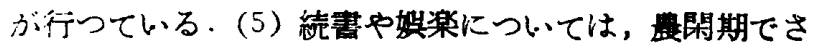
える主婦がまだまだ十分なし得ない状態にある、家族え の気がねなどがその主な理由のよらである（6）业䦥期 つ余啹の利用と，農村に於汁る封建思想の打破について 考える余地がある。

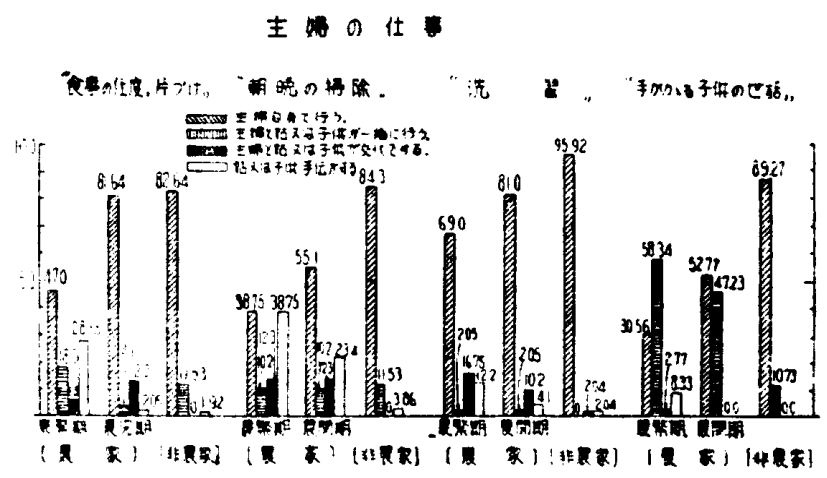

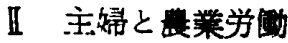

仕事の内容仕㐞子と较へて，特に重い物を持たな!・だ けで市，量共に大体同程度の事をしている．人手が少い 事や，若い主婦でよ家人への気がねがら少な身体の具合 が琴い特でも無理をする者もあり，妊娠時です頭初の間 は平常と大体同程度の筆をしている者が多い、一代事が きつい事が若い主婦にとつでつら心事であり，中年 以後の者は，むしろ貫事が思らようにはかとらないで， 他より革れる事を気にして少々の無理す我惯してい る.一

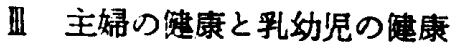

健康状態について異常を訴える者が多いが㢈病者が少 い.これは病気だとい5事の気がねからである事が二， 三の資糊から同われる。文妊娠中の建康猃断を受けてい、 ない者が乳児の死亡例に多く，生存例に少小結果を示 し，妊妘中の疾患は䄽児の生存例では見られないが，贯 村部に於て死亡例で琶められた。この事は分婏前に於汁

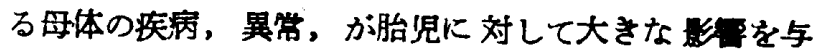

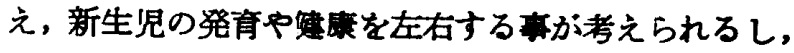

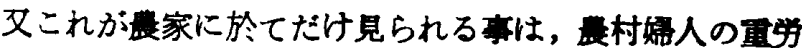
働による過労・や，封建性などによる妊娠と育胃期間を通 じての自分と乳児に対する健康上の麗虞の不足によるる のと推定される。

D. 結 語

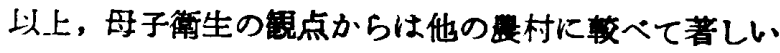
相違点はなく，贯繁期の労地が家事と重り合つて睡服時 間の短耯としであらわれ，これに加える家庭の諸事情は 一般に自由時間をるつ事を祑さず，娛楽に乏しく，奻

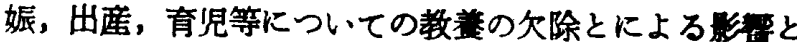

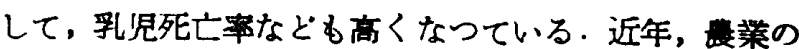
機械化により，労㽖力の軽娍，合理化が次第淮んで来 ているが，それと共に農繁期では，共同炊事，共同洗 濯，保育所などの社会運動を実施して，家事つ面での主 婦の負担の軽減，合理化を図るべきである，更に家庭内 の諸事情，就中，姑と嫁との関係についても PR そ行 つて, 所謂, 貫村の意識面での封建性をなくす事が必要 であろう、これらの努力がなされた時，主婦は自らの休 養時間を持つ事ぶ出来，それはそのま〉于共に対し，夫 に対し，姑に対しても明るさとなつて反映しよりよき 家筳が築かれて行く事になると考えるものである。 